\title{
Revised group classification of the genus Spiroplasma
}

\author{
David L. Williamson, ${ }^{1}$ Robert F. Whitcomb, ${ }^{2}$ Joseph G. Tully, ${ }^{3}$ Gail E. \\ Gasparich, ${ }^{4}+$ David L. Rose, ${ }^{3} \ddagger$ Patricia Carle, ${ }^{5}$ Joseph M. Bové, ${ }^{5}$ Kevin J. \\ Hackett, ${ }^{4}$ Jean R. Adams, Roberta B. Henegar, ${ }^{2}$ Meghnad Konai, ${ }^{4} \S$ \\ Claude Chastel $^{6}$ and Frank E. French ${ }^{7}$
}

\footnotetext{
1 Department of Anatomical Sciences, State University of New York, Stony Brook, NY 11794-8081, USA

2 Vegetable Laboratory, US Department of Agriculture, Beltsville, MD 20705, USA

3 Mycoplasma Section, Laboratory of Molecular Microbiology, National Institute of Allergy \& Infectious Diseases, Frederick Cancer Research Facility, Frederick, MD 21701, USA

4 Insect Biocontrol Laboratory, US Department of Agriculture, Beltsville, MD 20705, USA

5 Laboratoire de Biologie Cellulaire et Moléculaire, Institut Nationale de Recherche Agronomique, 33883 Villenave d'Ornon Cedex, France

6 Département de Microbiologie et Santé Publique, Faculté de Médecine, 29285 Brest Cedex, France

7 Department of Biology, Georgia Southern University, Statesboro, GA 30460, USA
}

Author for correspondence: David L. Williamson. Tel: + l 516444 3118. Fax: +1 5164443947. e-mail: dwmson@mail.som.sunysb.edu
Keywords: Spiroplasma, Mollicutes

Significant changes have been made in the systematics of the genus Spiroplasma (class Mollicutes) since it was expanded by revision in 1987 to include $\mathbf{2 3}$ groups and eight sub-groups. Since that time, two additional spiroplasmas have been assigned group numbers and species names. More recently, specific epithets have been assigned to nine previously designated groups and three sub-groups. Also, taxonomic descriptions and species names have been published for six previously ungrouped spiroplasmas. These six new organisms are: Spiroplasma alleghenense (strain PLHS-1') (group XXVI), Spiroplasma lineolae (strain TALS-2') (group XXVII), Spiroplasma platyhelix (strain PALS-1') (group XXVIII), Spiroplasma montanense (strain HYOS-1') (group XXXI), Spiroplasma helicoides (strain TABS-2') (group XXXII) and Spiroplasma tabanidicola (strain TAUS-1') (group XXXIII). Also, group XVII, which became vacant when strain DF-1' (Spiroplasma chrysopicola) was transferred to group VIII, has been filled with strain Tab 4c. The discovery of these strains reflects continuing primary search in insect reservoirs, particularly horse flies and deer flies (Diptera : Tabanidae). In the current revision, new group designations for 10 spiroplasma strains, including six recently named organisms, are proposed. Three unnamed but newly grouped spiroplasmas are strain TIUS-1 (group XXIX; ATCC 51751) from a typhiid wasp (Hymenoptera: Tiphiidae), strain BIUS-1 (group XXX; ATCC 51750) from floral surfaces of the tickseed sunflower (Bidens sp.) and strain BARC 1901 (group XXXIV; ATCC 700283). Strain BARC 2649 (ATCC 700284) from Tabanus lineola has been proposed as a new sub-group of group VIII. Strains TIUS-1 and BIUS-1 have unusual morphologies, appearing as helices at only certain stages in culture. In this revision, potentially important intergroup serological relationships observed between strain DW-1 (group II) from a neotropical Drosophila species and certain sub-group representatives of group I spiroplasmas are also reported.

\section{INTRODUCTION}

The group classification of spiroplasmas had its beginnings in 1976 when spiroplasma workers, under the auspices of the International Research Programme on Comparative Mycoplasmology and the International Subcommittee on the Taxonomy of Mollicutes, agreed to determine spiroplasma species concepts cooperatively (23). Five years later, the first group classification, which included five groups and

\footnotetext{
†Present address: Department of Biology, 324 A Smith Hall, Towson State University, Towson, MD 21252, USA.

¥Present address: 8602 Cinnamon Creek, San Antonio, TX 78284, USA.

§ Present address: 9125 Tymat Court, Laurel, MD 20723, USA.

Abbreviations: DF test, deformation test; MI test, metabolism inhibition test.
} 
four sub-groups, was proposed by Junca et al. (25). This informal classification scheme was later refined by proposal of criteria for groups and sub-groups (48) and by proposal of standards for assignment of species names to sub-groups. Three revisions of the Spiroplasma group classification were published $(42,48,51)$, resulting in an inventory of classified spiroplasmas of 23 groups and eight sub-groups by 1987.

Since then, the Chinese flower spiroplasma (strain $\mathrm{CCH}^{\mathrm{T}}$ ) has been designated to group XXV and named Spiroplasma chinense (16), and the CUAS- $1^{\mathrm{T}}$ mosquito spiroplasma was assigned to group XXV and named Spiroplasma diminutum (67). Also during this period, nine previously established Spiroplasma group representatives and three sub-group representatives were further characterized and, using standard criteria (24), assigned specific epithets. These included: group I, sub-group 6 (Spiroplasma insolitum, strain $\mathrm{M} 55^{\mathrm{T}}$ ) (21); group VII (Spiroplasma monobiae, strain MQ-1 ${ }^{\mathrm{T}}$ ) (61); group IX (Spiroplasma clarkii, strain $\mathrm{CN}-5^{\mathrm{T}}$ ) (63); group XI (Spiroplasma velocicrescens, strain MQ-4 ${ }^{\mathrm{T}}$ ) (28); group XII (Spiroplasma diabroticae, strain DU$1^{\mathrm{T}}$ ) (9); group XIV (Spiroplasma corruscae, strain EC$\left.1^{T}\right)(20)$; group XVI, sub-group 1 (Spiroplasma cantharicola, strain CC-1 ${ }^{\mathrm{T}}$ ) (49); group XVIII (Spiroplasma litorale, strain $\left.\mathrm{TN}-1^{\mathrm{T}}\right)$ (27), group XX (Spiroplasma leptinotarsae, strain LD-1 ${ }^{\mathrm{T}}$ ) (19); and group XXIII (Spiroplasma gladiatoris, strain TG-1 ${ }^{\mathrm{T}}$ ) (53).

In the case of group VIII sub-groups (13), strain EA$1^{\mathrm{T}}$, the initial sole representative of the group, was redesignated as group VIII, sub-group 1 and given the species name Spiroplasma syrphidicola (56). Strain DF-1 ${ }^{\mathrm{T}}$ (previously assigned to group XVII) was redesignated as group VIII, sub-group 2, and designated Spiroplasma chrysopicola (53). A tabanid strain (TAAS-1) was designated VIII-3. These changes left group XVII vacant. A spiroplasma (strain Tab 4c) from tabanid flies in France has recently been characterized and found to be unrelated to other established groups or sub-groups. Strain Tab $4 \mathrm{c}$ has been assigned to group XVII (22).

More recently, eight additional spiroplasma strains were reported to be unassignable to any of the existing 25 groups (71). Six of these strains were considered to represent significant additions to the genus Spiroplasma and have been recently named. These include group XXVI (Spiroplasma alleghenense, strain PLHS$1^{\mathrm{T}}$ ) (2), group XXVII (Spiroplasma lineolae, strain TALS- $1^{\mathrm{T}}$ ) (12), group XXVIII (Spiroplasma platyhelix, strain PALS-1 ${ }^{\mathrm{T}}$ ) (65), group XXXI (Spiroplasma montanense, strain HYOS-1 ${ }^{\mathrm{T}}$ ) (54), group XXXII (Spiroplasma helicoides, strain TABS-2 ${ }^{\mathrm{T}}$ ) (53) and group XXXIII (Spiroplasma tabanidicola, strain TAUS-1 $\left.{ }^{\mathrm{T}}\right)(53)$.

In this revision, we present a revised Spiroplasma group classification, and list species names (where available), type strains and numbers, major biochemical and genomic characteristics, and host origin of the organisms. We also report experimental work fulfilling criteria (48) for designation of three new spiroplasma groups. These new groups represent strains from both plants and insects, including strain TIUS-1 (group XXIX, ATCC 51751) from a typhiid wasp (Hymenoptera: Tiphiidae) and strain BIUS-1 (group XXX, ATCC 51750) from the floral surface of Bidens (tickseed sunflower) flowers. Strains TIUS-1 and BIUS-1 have unusual morphologies and/or growth cycles in culture. We also provide a group assignment (XXXIV) for a new strain, BARC 1901 (ATCC 700283) (52), from Tabanus lineola horse flies. Strain BARC 2649 (ATCC 700284), which appeared at first to represent a new group, is identified as a representative of a candidate new sub-group of group VIII.

We also report some recent and potentially important intergroup relationships between the group II representative strain DW-1 (the sex ratio spiroplasma from a neotropical Drosophila species) and various members of the eight sub-groups within group I spiroplasmas.

\section{METHODS}

Spiroplasma strains. The plant and insect spiroplasma strains whose properties are described here were isolated using standard techniques $(11,29)$. Strain TIUS-1 was isolated from an unknown species of the insect family Tiphiidae (order Hymenoptera) collected by T. B. Clark on 27 May 1983, in Beltsville, MD, USA. After primary isolation, the strain was thought to be non-helical, but helical forms of the organism were noted after several passages in culture media. Strain BIUS-1 was isolated from a Bidens sp. flower surface by K. J. Hackett on 11 September 1983, in Beltsville, MD, USA. Strains BARC 1901 and BARC 2649 were isolated from gut contents of Tabanus lineola collected in Georgia, USA, in 1995 by F. E. French and colleagues (52).

Culture medium and cultivation techniques. Spiroplasmas were grown in M1D liquid broth (47) at $30^{\circ} \mathrm{C}$, a temperature at which most spiroplasma species grow well (26). The strains were cloned $(38,58)$ in M1D broth and on M1D solid medium. Other culture media used were SP-4 (47), conventional horse serum medium, and serum-fraction broth containing $1 \%$ bovine serum fraction (Difco) (39).

Morphological studies. Cells of strains cultivated in M1D broth were examined during exponential phase at a magnification of $\times 1250$ by dark-field microscopy (37). For electron microscopic examination of membrane structure, exponential-phase cultures of approximately $2 \mathrm{ml}$ in M1D broth were pelleted by centrifugation at $4^{\circ} \mathrm{C}$. Most pellets were fixed for $2 \mathrm{~h}$ in $3 \%$ glutaraldehyde in phosphate buffer (pH 7.3) supplemented with $0 \cdot 25 \mathrm{M}$ sucrose. In some cases, higher molarities of sucrose were used. The pellets were then postfixed in Palade-buffered 1\% osmium tetroxide for $1 \mathrm{~h}$, dehydrated in acetone and embedded in Spurr low-viscocity embedding medium. The prepared blocks were sectioned at $60-90 \mathrm{~nm}$, and sections were stained with $1 \%$ aqueous uranyl acetate and Reynold's lead citrate (64).

Serological tests. Antiserum to the four spiroplasmas was raised in rabbits as previously described (68). Hyperimmune antisera to all established groups, putative groups, and sub- 
Table 1. Revised classification of spiroplasmas

\begin{tabular}{|c|c|c|c|c|c|}
\hline Group & Species & $\begin{array}{c}\text { Representative strain } \\
\text { (ATCC) }\end{array}$ & $\begin{array}{c}G+C \\
( \pm 1 \mathrm{~mol} \%)\end{array}$ & $\begin{array}{l}\text { Glucose/ } \\
\text { arginine }\end{array}$ & Host/habitat \\
\hline $\mathrm{I}-1$ & S. citri & Maroc-R8A2 $2^{\mathrm{T}}(27556)$ & 26 & $+/+$ & Phloem/leafhopper \\
\hline $\mathrm{I}-2$ & S. melliferum & $\mathrm{BC}-3^{\mathrm{T}}(33219)$ & 26 & $+/+$ & Honey bee \\
\hline $\mathrm{I}-3$ & S. kunkelii & $\mathrm{E} 275^{\mathrm{T}}(29320)$ & 26 & $+/+$ & Phloem/leafhopper \\
\hline $\mathrm{I}-4$ & & $277 \mathrm{~F}(29761)$ & 26 & $+/+$ & Rabbit tick \\
\hline $\mathrm{I}-5$ & & LB-12 (33649) & 26 & $+1-$ & Plant bug \\
\hline $\mathrm{I}-6$ & S. insolitum & $\mathrm{M}^{2} 5^{\mathrm{T}}(33502)$ & 26 & $+1-$ & Flower surface \\
\hline $\mathrm{I}-7$ & & N525 (33287) & 26 & $+1+$ & Plant surface \\
\hline $\mathrm{I}-8$ & S. phoeniceum & $\mathrm{P} 40^{\mathrm{T}}(43115)$ & 26 & $+/+$ & Phloem/vector \\
\hline II & & DW-1 (43153) & 26 & ND & Drosophila \\
\hline III & S. floricola & $23-6^{\mathrm{T}}(29989)$ & 26 & $+1-$ & Plant surface \\
\hline IV & S. apis & $\mathrm{B} 31^{\mathrm{T}}(33834)$ & 30 & $+1-$ & Honey bee \\
\hline $\mathrm{V}$ & $S$. mirum & $\operatorname{SMCA}^{\mathrm{T}}(29335)$ & 30 & $+1+$ & Rabbit tick \\
\hline VI & S. ixodetis & $\mathrm{Y} 32^{\mathrm{T}}(33835)$ & 25 & $+1-$ & Ixodid tick \\
\hline VII & S. monobiae & MQ-1 ${ }^{\mathrm{T}}(33825)$ & 28 & $+1-$ & Monobia wasp \\
\hline VIII-1 & S. syrphidicola & $\mathrm{EA}^{-1}{ }^{\mathrm{T}}(33826)$ & 30 & $+/+$ & Syrphid fly \\
\hline VIII-2 & S. chrysopicola & $\mathrm{DF}-1^{\mathrm{T}}(43209)$ & 29 & $+/-$ & Deer fly \\
\hline VIII-3 & & TAAS-1 (51123) & 31 & $+/+$ & Horse fly \\
\hline IX & S. clarkii & $\mathrm{CN}-5^{\mathrm{T}}(33827)$ & 29 & $+/+$ & Green June beetle \\
\hline$X$ & S. culicicola & AES-1 ${ }^{\mathrm{T}}(35112)$ & 26 & $+1-$ & Mosquito \\
\hline XI & S. velocicrescens & MQ-4 $4^{\mathrm{T}}(35262)$ & 26 & $+1-$ & Monobia wasp \\
\hline XII & S. diabroticae & DU-1 ${ }^{\mathrm{T}}(43210)$ & 25 & $+1-$ & Beetle \\
\hline XIII & S. sabaudiense & Ar- $1343^{\mathrm{T}}(43303)$ & 29 & $+/-$ & Mosquito \\
\hline XIV & S. corruscae & $\mathrm{EC}-1^{\mathrm{T}}(43212)$ & 26 & $+1-$ & Horse fly/beetle \\
\hline XV & & I-25 (43262) & 26 & $+1-$ & Leafhopper \\
\hline XVI-1 & S. cantharicola & $C C-1^{\mathrm{T}}(43207)$ & 26 & $+1-$ & Cantharid beetle \\
\hline XVI-2 & & CB-1 (43208) & 26 & $+1-$ & Cantharid beetle \\
\hline XVI-3 & & Ar-1357 (51126) & 26 & $+1-$ & Mosquito \\
\hline XVII & & Tab 4c (700271) & 25 & $+1-$ & Horse fly \\
\hline XVIII & S. litorale & $\mathrm{TN}-1^{\mathrm{T}}(43211)$ & 25 & $+1-$ & Horse fly \\
\hline XIX & S. lampyridicola & PUP-1 ${ }^{\mathrm{T}}(43206)$ & 25 & $+1-$ & Firefly \\
\hline $\mathrm{XX}$ & S. leptinotarsae & $\mathrm{LD}^{-1}{ }^{\mathrm{T}}(43213)$ & 25 & $+/+$ & Colorado potato beetle \\
\hline XXI & & W115 (43260) & 24 & $+/-$ & Flower surface \\
\hline XXII & S. taiwanense & $\mathrm{CT}-1^{\mathrm{T}}(43302)$ & 26 & $+1-$ & Culex mosquito \\
\hline XXIII & S. gladiatoris & TG- $1^{\mathrm{T}}(43225)$ & 26 & $+1-$ & Horse fly \\
\hline XXIV & S. chinense & $\mathrm{CCH}^{\mathrm{T}}(43960)$ & 29 & $+1-$ & Flower surface \\
\hline XXV & S. diminutum & CUAS- ${ }^{\mathrm{T}}(49235)$ & 26 & $+1-$ & Culex mosquito \\
\hline XXVI & S. alleghenense & PLHS- $1^{\mathrm{T}}(51752)$ & 31 & $+/+$ & Scorpionfly \\
\hline XXVII & S. lineolae & TALS-2 ${ }^{\mathrm{T}}(51749)$ & 25 & $+1-$ & Horse fly \\
\hline XXVIII & S. platyhelix & PALS- $1^{\mathrm{T}}(51748)$ & 29 & $+/+$ & Dragonfly \\
\hline XXIX & & TIUS-1 (51751) & 28 & $+/-$ & Tiphiid wasp \\
\hline XXX & & BIUS-1 (51750) & 28 & $+/-$ & Flower surface \\
\hline XXXI & S. montanense & HYOS- $1^{\mathrm{T}}(51745)$ & 28 & $+/+$ & Horse fly \\
\hline XXXII & S. helicoides & TABS- $2^{\mathrm{T}}(51746)$ & 27 & $+1-$ & Horse fly \\
\hline XXXIII & S. tabanidicola & TAUS-1 ${ }^{\mathrm{T}}(51747)$ & 26 & $+/-$ & Horse fly \\
\hline \multirow[t]{2}{*}{ XXXIV } & & BARC 1901 (700283) & 25 & $+1-$ & Horse fly \\
\hline & & BARC 2649 (700284) & 28 & $+/+$ & Horse fly \\
\hline
\end{tabular}

groups $(16,41,42,62,67,71)$ of the genus Spiroplasma (Table 1) were taken from the reference collections at the Beltsville Agricultural Research Center and the National Institute of Allergy and Infectious Diseases laboratory in Frederick, MD, USA. Antisera and spiroplasmas were tested reciprocally in metabolism inhibition (MI) $(68,69)$ and spiroplasma deformation (DF) tests $(55,57,68,69,70)$.
In these tests, serological relationships between candidate strains and existing strains were indicated by reciprocal cross-reactions with the candidate strain represented by antigen or antiserum. The existence of reciprocal serological cross-reactions in both tests was deemed a reliable indicator of relationships. In rare cases, the propensity of some strains to exhibit one-way crosses made this determination difficult. 
Table 2. Serological reactivities of newly proposed spiroplasma group representatives (in bold)

Antigen and antisera of the strains were tested in all heterologous combinations against all known and putative groups and sub-groups. All cross-reactions were negative (-) except where shown. Values in the 'Antigen' columns are reciprocals of end points in which the designated antigen was tested versus heterologous antiserum. Values in 'Antiserum' columns are reciprocals of end points in which the designated antiserum was tested versus heterologous antiserum.

\begin{tabular}{|c|c|c|c|c|}
\hline \multirow[t]{2}{*}{ Group/strain } & \multicolumn{2}{|c|}{ Deformation } & \multicolumn{2}{|c|}{ Metabolism inhibition } \\
\hline & Antigen & Antiserum & Antigen & Antiserum \\
\hline \multicolumn{5}{|c|}{ Strain TIUS-1 (group XXIX) } \\
\hline $\mathrm{I}-3 / \mathrm{E} 275^{\mathrm{T}}$ & - & - & 54 & - \\
\hline I-7/N525 & 20 & - & - & - \\
\hline II/DW-1 & - & - & - & 18 \\
\hline VIII-3/TAAS-1 & - & - & 18 & - \\
\hline XIII/Ar-1343 & - & - & 54 & - \\
\hline $\mathrm{XIV} / \mathrm{EC}-1^{\mathrm{T}}$ & - & - & 54 & - \\
\hline XVI-2/CB-1 & - & - & 18 & - \\
\hline XVI-3/Ar-1357 & - & - & 18 & - \\
\hline XIX/PUP-1 ${ }^{\mathrm{T}}$ & - & - & - & 162 \\
\hline XXI/W115 & - & - & - & 18 \\
\hline $\mathrm{XXII} / \mathrm{CT}-1^{\mathrm{T}}$ & - & 20 & - & - \\
\hline XXVI/PLHS- $1^{\mathrm{T}}$ & - & - & - & 162 \\
\hline XXVII/TALS-2 $2^{\mathrm{T}}$ & - & - & 18 & - \\
\hline XXIX/TIUS-1 & $640^{*}$ & $640^{*}$ & $39000^{*}$ & $39000^{*}$ \\
\hline \multicolumn{5}{|c|}{ Strain BIUS-1 (group XXX) } \\
\hline $\mathrm{I}-1 / \mathrm{R} 8 \mathrm{~A} 2^{\mathrm{T}}$ & 20 & - & - & - \\
\hline $\mathrm{I}-4 / 277 \mathrm{~F}$ & - & - & - & 1458 \\
\hline I-5/LB-12 & - & - & - & 54 \\
\hline $\mathrm{I}-7 / \mathrm{N} 525$ & - & - & - & 54 \\
\hline II/DW-1 & - & - & - & 18 \\
\hline III $/ 23-6^{\mathrm{T}}$ & 160 & 20 & - & 1458 \\
\hline $\mathrm{IV} / \mathrm{B} 31^{\mathrm{T}}$ & - & - & 18 & - \\
\hline $\mathrm{VII} / \mathrm{MQ}-1^{\mathrm{T}}$ & 80 & - & - & 486 \\
\hline VIII-2/DF-1 ${ }^{\mathrm{T}}$ & - & - & 18 & - \\
\hline VIII-3/TAAS-1 & - & - & 54 & - \\
\hline $\mathrm{XI} / \mathrm{MQ}-4^{\mathrm{T}}$ & 20 & - & - & - \\
\hline $\mathrm{XII} / \mathrm{DU}-1^{\mathrm{T}}$ & 1280 & - & 162 & - \\
\hline XIII/Ar-1343 & - & - & 18 & - \\
\hline $\mathrm{XV} / \mathrm{I}-25$ & - & - & 54 & - \\
\hline XVIII/TN-1 ${ }^{\mathrm{T}}$ & - & - & 18 & - \\
\hline XIX/PUP-1 ${ }^{\mathrm{T}}$ & - & 40 & - & 1458 \\
\hline $\mathrm{XX} / \mathrm{LD}-1^{\mathrm{T}}$ & - & - & - & 54 \\
\hline $\mathrm{XXIII} / \mathrm{TG}-1^{\mathrm{T}}$ & - & - & 18 & - \\
\hline XXVI/PLHS-1 ${ }^{\mathrm{T}}$ & - & 40 & - & 1458 \\
\hline XXVIII/PALS- $1^{\mathrm{T}}$ & - & - & - & 486 \\
\hline XXX/BIUS-1 & $10240^{*}$ & $10240^{*}$ & $39000^{*}$ & $39000^{*}$ \\
\hline XXXIII/TAUS- $1^{\mathrm{T}}$ & - & - & 18 & - \\
\hline XXXIV/BARC 1901 & 160 & - & - & - \\
\hline BARC 2649 & 20 & - & - & - \\
\hline \multicolumn{5}{|c|}{ Strain BARC 1901 (group XXXIV) } \\
\hline I-5/LB-12 & - & - & 18 & - \\
\hline $\mathrm{I}-6 / \mathrm{M} 55^{\mathrm{T}}$ & - & - & 18 & - \\
\hline I-7/N525 & - & - & 18 & - \\
\hline $\mathrm{I}-8 / \mathrm{P} 40^{\mathrm{T}}$ & - & - & 18 & - \\
\hline
\end{tabular}


Table 2 (cont.)

\begin{tabular}{|c|c|c|c|c|}
\hline \multirow[t]{2}{*}{ Group/strain } & \multicolumn{2}{|c|}{ Deformation } & \multicolumn{2}{|c|}{ Metabolism inhibition } \\
\hline & Antigen & Antiserum & Antigen & Antiserum \\
\hline \multicolumn{5}{|c|}{ Strain BARC 1901 (cont.) } \\
\hline II/DW-1 & - & - & - & 486 \\
\hline $\mathrm{IV} / \mathrm{B} 31^{\mathrm{T}}$ & - & - & - & 54 \\
\hline $\mathrm{VII} / \mathrm{MQ}-1^{\mathrm{T}}$ & - & 20 & - & 54 \\
\hline VIII-1/EA-1 & - & - & 18 & - \\
\hline VIII-2/DF-1 ${ }^{\mathrm{T}}$ & - & - & - & 18 \\
\hline VIII-3/TAAS-1 & - & 20 & - & - \\
\hline $\mathrm{IX} / \mathrm{CN}-5^{\mathrm{T}}$ & - & - & 18 & - \\
\hline $\mathrm{XIII} / \mathrm{Ar}-1343^{\mathrm{T}}$ & - & - & 18 & - \\
\hline $\mathrm{XV} / \mathrm{I}-25$ & - & - & 18 & - \\
\hline XVI-3/Ar-1357 & - & - & 18 & - \\
\hline XIX/PUP-1 ${ }^{\mathrm{T}}$ & - & 20 & - & 4374 \\
\hline XXII/CT- $1^{\mathrm{T}}$ & - & - & - & 18 \\
\hline XXVI/PLHS-1 ${ }^{\mathrm{T}}$ & - & - & - & 54 \\
\hline XXVII/TALS-2 $2^{T}$ & - & - & - & 54 \\
\hline XXVIII/PALS-1 ${ }^{\mathrm{T}}$ & - & - & - & 162 \\
\hline XXX/BIUS-1 & - & 160 & - & - \\
\hline XXXIV/BARC 1901 & $320^{*}$ & $320^{*}$ & $39000^{*}$ & $39000^{*}$ \\
\hline \multicolumn{5}{|l|}{ Strain BARC 2649} \\
\hline II/DW-1 & - & - & - & 1458 \\
\hline VIII-1 $/$ EA-1 ${ }^{\mathrm{T}}$ & - & - & 486 & - \\
\hline VIII- $2 / D F-1^{\mathrm{T}}$ & - & - & - & 54 \\
\hline VIII-3/TAAS-1 & - & - & 486 & - \\
\hline $\mathrm{X} / \mathrm{AES}-^{\mathrm{T}}$ & - & - & 18 & - \\
\hline $\mathrm{XIII} / \mathrm{Ar}-1343^{\mathrm{T}}$ & - & - & - & 18 \\
\hline XVII/Tab 4c & - & - & 24 & - \\
\hline XIX/PUP-1 ${ }^{\mathrm{T}}$ & - & 20 & - & 4374 \\
\hline $\mathrm{XX} / \mathrm{LD}^{-1^{\mathrm{T}}}$ & - & - & 18 & - \\
\hline XXI/W115 & - & - & 18 & - \\
\hline $\mathrm{XXV} /$ CUAS- $1^{\mathrm{T}}$ & - & - & 18 & - \\
\hline XXVI/PLHS- $1^{\mathrm{T}}$ & - & 20 & - & 18 \\
\hline XXX/BIUS-1 & - & 20 & - & - \\
\hline XXXII/TABS-2 $2^{\mathrm{T}}$ & - & - & 4374 & - \\
\hline BARC 2649 & $320^{*}$ & $320^{*}$ & $117000^{*}$ & $117000^{*}$ \\
\hline
\end{tabular}

${ }^{*}$ Homologous titres of the strains in the respective test system. The reaction, obtained only once, is listed in each column for completeness.

On the other hand, some relationships that have been eventually established by genomic studies $(5,6)$ are reflected only by one-way crosses. For these reasons, it was necessary to consider the results of both MI and DF tests in assessing relationships.

Biochemical tests. Strains were examined by standard methods for their ability to utilize glucose (3), arginine (17) and urea (3). Prior to testing, each strain was adapted to conventional mycoplasma medium supplemented with $1 \%$ bovine serum fraction.

Genomic determinations. $G+C$ content of the DNA of the strains was determined by buoyant density and melting temperature as previously described $(7,8)$. The genome size of some strains was measured by $\operatorname{PFGE}(5,14)$.

\section{RESULTS}

\section{Serological reactions}

Four candidate strains were included in this study: TIUS-1, BIUS-1, BARC 1901 and BARC 2649. Reciprocal serological tests (Table 2) between these strains and representatives of all existing spiroplasma groups and sub-groups indicated that three of the candidate strains (TIUS-1, BIUS-1 and BARC 1901) are unrelated to known taxa or to previously defined spiroplasma groups or sub-groups, or to each other. Strains BARC 1901 and BARC 2649 showed variable crossing patterns with some group strains, especially in the MI test. Some serological analyses of strains BARC 
Table 3. Serological reactivities of the group II spiroplasma strain DW-1

See the legend to Table 2 .

\begin{tabular}{|c|c|c|c|c|}
\hline \multirow[t]{2}{*}{ Group/strain } & \multicolumn{2}{|c|}{ Deformation } & \multicolumn{2}{|c|}{ Metabolism inhibition } \\
\hline & Antigen & Antiserum & Antigen & Antiserum \\
\hline \multicolumn{5}{|l|}{ Strain DW-1 (group II) } \\
\hline $\mathrm{I}-1 / \mathrm{R} 8 \mathrm{~A} 2^{\mathrm{T}}$ & 20 & 20 & 162 & - \\
\hline $\mathrm{I}-2 / \mathrm{BC}-3^{\mathrm{T}}$ & 160 & - & 486 & 54 \\
\hline $\mathrm{I}-3 / \mathrm{E} 275^{\mathrm{T}}$ & 160 & 20 & 486 & - \\
\hline $\mathrm{I}-4 / 277 \mathrm{~F}$ & 160 & 80 & 4374 & - \\
\hline I-5/LB-12 & 160 & - & 39000 & - \\
\hline I-6/M55 & 320 & 20 & 4374 & - \\
\hline I-7/N525 & 320 & 40 & 39000 & - \\
\hline $\mathrm{I}-8 / \mathrm{P} 40^{\mathrm{T}}$ & 640 & 20 & 1458 & 54 \\
\hline $\mathrm{II} / \mathrm{DW}-1$ & $1280^{*}$ & $1280^{*}$ & $>117000^{*}$ & $>117000^{*}$ \\
\hline III $/ 23-6^{\mathrm{T}}$ & - & - & 18 & - \\
\hline $\mathrm{IV} / \mathrm{B} 31^{\mathrm{T}}$ & 20 & - & 54 & - \\
\hline $\mathrm{VI} / \mathrm{Y} 32^{\mathrm{T}}$ & - & - & 18 & - \\
\hline $\mathrm{VII} / \mathrm{MQ}-1^{\mathrm{T}}$ & - & - & 54 & - \\
\hline VIII-1 $/$ EA-1 $^{\mathrm{T}}$ & - & - & 54 & - \\
\hline VIII-2/DF-1 ${ }^{\mathrm{T}}$ & - & - & 1458 & -- \\
\hline $\mathrm{IX} / \mathrm{CN}-5^{\mathrm{T}}$ & - & - & 162 & - \\
\hline $\mathrm{X} / \mathrm{AES}-\mathrm{1}^{\mathrm{T}}$ & - & - & 486 & - \\
\hline $\mathrm{XII} / \mathrm{DU}-1^{\mathrm{T}}$ & - & - & 18 & - \\
\hline $\mathrm{XIII} / \mathrm{Ar}-1343^{\mathrm{T}}$ & - & - & 54 & - \\
\hline $\mathrm{XV} / \mathrm{I}-25$ & - & - & 54 & - \\
\hline $\mathrm{XVI}-1 / \mathrm{CC}-1^{\mathrm{T}}$ & 20 & - & - & - \\
\hline XVI-2/CB-1 & - & - & 54 & - \\
\hline XVI-3/Ar-1357 & - & - & 54 & - \\
\hline $\mathrm{XVIII} / \mathrm{TN}-1^{\mathrm{T}}$ & 40 & - & 18 & - \\
\hline XIX/PUP- $1^{\mathrm{T}}$ & - & 40 & 18 & - \\
\hline $\mathrm{XX} / \mathrm{LD}-\mathrm{1}^{\mathrm{T}}$ & - & - & 54 & 18 \\
\hline XXI/W115 & - & - & 18 & - \\
\hline $\mathrm{XXII} / \mathrm{CT}-1^{\mathrm{T}}$ & - & - & 18 & - \\
\hline XXIII $/$ TG- $^{\mathrm{T}}$ & - & - & 54 & - \\
\hline $\mathrm{XXIV} / \mathrm{CCH}^{\mathrm{T}}$ & - & - & 18 & - \\
\hline $\mathrm{XXV} / \mathrm{CUAS}^{-1^{\mathrm{T}}}$ & 20 & - & 18 & - \\
\hline XXVI/PLHS- $1^{\mathrm{T}}$ & - & - & - & 54 \\
\hline XXIX/TIUS-1 & - & - & 18 & - \\
\hline XXX/BIUS-1 & - & - & 18 & - \\
\hline XXXI/HYOS $-1^{\mathrm{T}}$ & - & - & 54 & - \\
\hline XXXII/TABS-2 $2^{T}$ & - & - & 18 & - \\
\hline XXXIII/TAUS-1 ${ }^{\mathrm{T}}$ & - & - & 18 & - \\
\hline XXXIV/BARC 1901 & - & - & 486 & - \\
\hline BARC 2649 & - & - & 1458 & - \\
\hline
\end{tabular}

* See footnote to Table 2 .

1901 and BARC 2649 are reported elsewhere (52) in a comparison of spiroplasmas from tabanid hosts.

In the serological analyses performed for this study, we observed relatively high levels of serological cross reactivity between group II strain DW-1 spiroplasmas and group I antisera (Table 3). In two reciprocal group I vs group II comparisons (strain DW-1 vs sub-group I-3 strain E275 ${ }^{\mathrm{T}}$, and sub-group I-8 strain $\mathrm{P} 40^{\mathrm{T}}$ ), crosses were observed in both directions with both techniques.

\section{Biochemical tests}

All four candidate strains produced acid from glucose, but only BARC 2649 was able to hydrolyse arginine. None hydrolysed urea. 

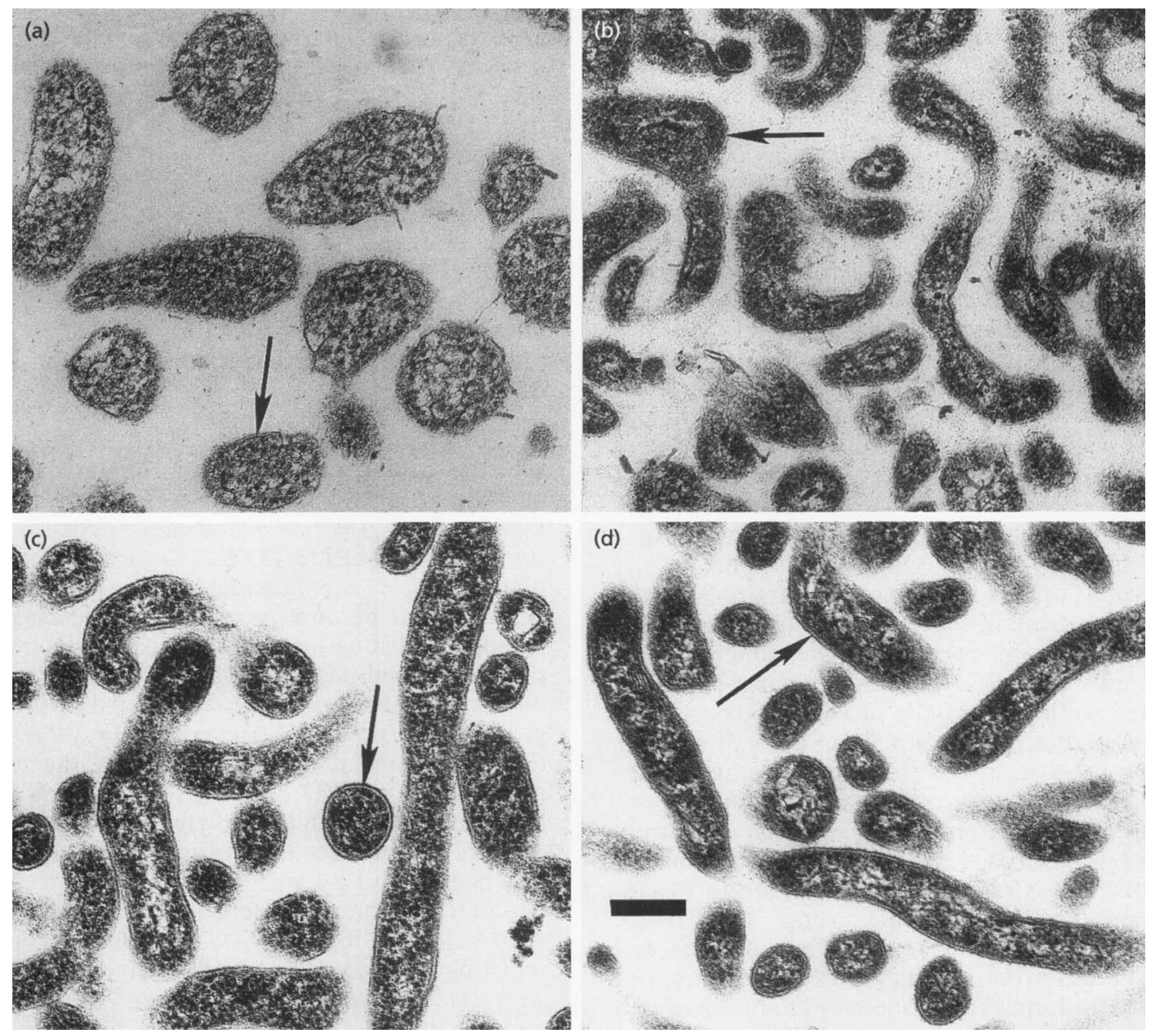

Fig. 1. Electron micrograph of cells of strains (a) TIUS-1, (b) BIUS-1, (c) BARC 1901 and (d) BARC 2649. Arrows indicate unit membrane. Bar, $200 \mathrm{~nm}$.

\section{Morphology}

Strains BIUS-1 and TIUS-1 were unusual in that they often appeared to grow in a non-helical form when examined by conventional dark-field techniques. Each of these strains, however, exhibited motile helical forms in late-exponential or early-stationary phase, at a time when the medium appeared to approach its lowest $\mathrm{pH}(6.0)$ from acid production by glucose fermentation. Electron microscopic observations revealed (Fig. 1a, b) that the cells were bound by a single cytoplasmic membrane.

Strains BARC 1901 and BARC 2649, when grown in M1D broth medium, exhibited typical spiroplasma morphology in dark-field microscopy. Cells of strain BARC 1901 possessed long helices with six or more turns, but cells of strain BARC 2649 exhibited short helices with less than six turns. Ultrastructural examination of cells of both strains showed that the cells of both strains were bound only by a single cytoplasmic membrane (Fig. 1c, d).

\section{$\mathbf{G}+\mathbf{C}$ content of DNA}

The $\mathrm{G}+\mathrm{C}$ content $( \pm 1 \mathrm{~mol} \%)$ of the strains were: TIUS-1, 28; BIUS-1, 28 ; BARC 1901, 25; and BARC 2649,28 . The genome (in $\mathrm{kbp}$ ) of strain TIUS-1 was 840 , and of strain BARC 2649 was 1325 .

\section{DISCUSSION}

Table 1 reflects recent corrections to earlier data (42) on the responses of sub-groups I-5 and I-6 to tests for glucose fermentation and arginine hydrolysis. We also hereby correct the identification of several spiroplasmas in electron micrographs in the 1987 publication by Tully et al. (42). Figs $1(\mathrm{H}, \mathrm{I})$ of that report 
actually show cell membranes of group XXI strain W115 and group XXIII strain TG- $1^{\mathrm{T}}$. An electron micrograph of group $\mathrm{XX}$ strain $\mathrm{LD}-1^{\mathrm{T}}$ was inadvertently omitted from Fig. 1, but has been recently published (19).

To complete the serological comparisons required to establish the serological classification of spiroplasmas, 3362 serological cross-reactions (1681 tests in reciprocal sets of both DF and MI test procedures) were done. Although laborious to complete, this data set gives a reasonable basis for assessing serological relationships among spiroplasmas. Valid relationships (i.e. those confirmed by other criteria) are usually reflected by complete reciprocity in DF and MI tests. This is not universally so; the relatedness among sub-groups of group VIII (13) and group XVI $(1,49)$ was obscured at first by a lack of reciprocity in DF or MI tests between some strains in the matrix of interrelated organisms. Growth inhibition tests (60), although applied earlier to some groups $(42,51,59,60)$ were abandoned as the matrices to be compared grew larger and larger. The meaning of the many one-way crosses among spiroplasma strains is unclear. Of course, when a pair of spiroplasma strains eventually proves to be part of an interrelated matrix (e.g. group VIII and XVI strains), the one-way cross-reactions are clearly meaningful. On the other hand, some spiroplasmas, including especially group XIX (Spiroplasma lampyridicola, strain PUP-1 ${ }^{\mathrm{T}}$ ) (35), group XX (S. leptinotarsae, strain LD$\left.1^{\mathrm{T}}\right)(19)$, group XXVI $(S$. alleghenense, strain PLHS$\left.1^{\mathrm{T}}\right)(2)$, and to some extent, group XXVIII ( $S$. platyhelix, strain PALS-1 ${ }^{\mathrm{T}}$ ) (65), when used as test antigens, reacted promiscuously with a broad array of spiroplasma antisera. These one-way crosses involve a large number of spiroplasma pairs that show no other related feature. Such pairs often have very discrepant $\mathrm{G}+\mathrm{C}$ contents, different glucose/arginine utilization patterns, different host or geographic origins and, when tested, share little or no DNA-DNA homology. Such one-way crosses can be clearly seen to be spurious and must be ignored. However, the meaning of oneway crosses observed with spiroplasmas that do not show a promiscuous one-way crossing pattern is much less clear, and probably needs to be examined in the context of a polyphasic (44) classification of spiroplasma species and groups. Analysis of 16S rDNA sequences of various mollicutes, where available (15, $36,45,46)$, would provide an excellent primary tool for such an analysis. It is not clear how useful whole genomic data (genome size and base composition) would be in intergroup classification. The variation in genome size among spiroplasmas $(5,6,30-32)$ is great, suggesting that this character is evolutionarily labile. $\mathrm{G}+\mathrm{C}$ contents are problematic, since values may vary substantially even within a group, as with $S$. insolitum (sub-group I-6), compared to other group I members (21). In general, with either genome size or $\mathrm{G}+\mathrm{C}$ contents, widely different values between strains indicate that the strains are different species; however, similar values are not unequivocally indicative of relationship, since both $\mathrm{G}+\mathrm{C}$ and genome size data are composite overall values that may be derived from genomes that may be very different genetically. With spiroplasmas, as with other mollicutes, DNA-DNA hybridization data continue to be the criterion of last resort in deciding whether to lump strains into a single species. For interspecies classifications, including cladistic reconstructions, $16 \mathrm{~S}$ rDNA sequence data are much more useful than any phenotypic characters. However, until sequence data are available for representatives of all spiroplasma groups and sub-groups, phenotypic characters, including serological data, will provide a basis for construction of polyphasic classifications.

The serological analyses provided in this paper revealed a hitherto unappreciated distant relationship between group I and the group II spiroplasma (strain DW-1) from Drosophila species. Because group I spiroplasmas $(4,11,33,34,50)$ are associated with plant diseases, sap-sucking insects, ticks and flower surfaces, and because group II spiroplasmas are very fastidious host-associated organisms that induce sexratio abnormalities in their Drosophila hosts (66), this relationship had not been suspected. Furthermore, group II spiroplasmas are extremely difficult to cultivate in artificial medium (18), and the tests summarized in the 1987 revision (42) had, by necessity, been performed with haemolymph-derived antigens. It is interesting to note that group I and II spiroplasmas had been found by Weisburg et al. (46) to be closely clustered in the phylogenetic analysis of their $16 \mathrm{~S}$ rDNA. In addition, the $\mathrm{G}+\mathrm{C}$ content of their DNA is indistinguishable (42). Further clarification of this suggested relationship may eventually require an attempt to assess the DNA-DNA homology between group I and group II spiroplasmas.

Data from partial serological crossing may occasionally provide an inaccurate impression of intergroup relationships. Thus, in 1992, it was proposed (59) that the CUAS- $1^{\mathrm{T}}$ strain from mosquitoes and the group VII S. monobiae, MQ- $1^{\mathrm{T}}$ strain from a Monobia wasp were serologically related, and perhaps represented sub-groups of a single group. However, analysis of the polyphasic set of characters for the two groups, particularly genome size, established that strain CUAS- $1^{\mathrm{T}}$ was in fact distinct from strain MQ- $1^{\mathrm{T}}$ and all other existing groups. This strain was eventually described as a new species ( $S$. diminutum) (group XXV) (67) in the current classification scheme.

Recent studies of an extensive collection of tabanid spiroplasmas (52) have suggested the possibility of a cluster of strains that includes groups XXIII, XXVII, XXXII, XXXIII and possibly other strains. All of the strains exhibit aggressive glucose fermentation, fail to hydrolyse arginine, and have a $\mathrm{G}+\mathrm{C}$ content of 25-27 mol \%. In addition, these strains, and some related strains, show a complex pattern of interrelationships in one-way serological crosses (52). It may be necessary to perform $16 \mathrm{~S}$ rDNA sequence 
Revised group classification of genus Spiroplasma

analysis to test the hypothesis that these spiroplasma may form a monophyletic spiroplasma clade.

Also, sequence analysis of $16 \mathrm{~S}$ rDNA will probably be necessary to clarify several other interesting questions concerning some of the spiroplasmas designated herein. The morphologies of $S$. platyhelix (strain PALS$1^{\mathrm{T}}$ ), and strains TIUS-1, and BIUS-1 reported here are unusual for spiroplasmas, and it is possible that one or more of these strains could represent paraphyletic lineage(s). The group VI Spiroplasma ixodetis (43) strain $\mathrm{Y} 32^{\mathrm{T}}$ presented a similar dilemma, in that its morphology also differed substantially from that of conventional spiroplasmas. In this instance, $16 \mathrm{~S}$ rDNA analysis (46) confirmed the monophyly of the $\mathrm{Y} 32^{\mathrm{T}}$ strain and other spiroplasmas.

Since the last revision, the concept of spiroplasma subgroups has undergone subtle modification. In both group VIII (13) and XVI spiroplasmas $(1,49)$, there are now sub-groups that represent some of the known variability within the group. When we attempted to apply this classification to a large existing cluster of spiroplasma isolates from tabanids in Georgia, however, we were unable to place the most prevalent group VIII serovar in any of the existing sub-groups (52). Reciprocal serological analysis has subsequently shown that this serovar (strain BARC 1357) probably represents a fourth unrecognized sub-group of group VIII. The serological data presented here suggest that strain BARC 2649 represents a fifth unrecognized subgroup of group VIII. Other group VIII isolates from tabanid flies appear to differ considerably from any and all of these five representatives. The large number of possible sub-groups of this cluster, given the requirements for sub-group designation (48), appears to preclude their taxonomic designation.

Lastly, a phylogenetic analysis of mollicutes reported in 1989 (46) indicated that the spiroplasmas represent an important evolutionary divergence from the acholeplasma/anaeroplasma branch of mollicutes. From this lineage, one cluster of mycoplasmas evolved, which includes Mycoplasma mycoides, and a cluster of mollicutes (including those currently placed in Entomoplasma and Mesoplasma) from insects. These organisms and the major clades of mycoplasmas (e.g. Mycoplasma hominis and Mycoplasma pneumoniae) are polyphyletic. These major phylogenetic distinctions prompted a proposed revision in the classification of the class Mollicutes (40). In this revision, the order Entomoplasmatales was created to provide taxonomic status for the emerging collections of arthropodassociated mollicutes, including the spiroplasmas (family Spiroplasmataceae, genus Spiroplasma) and for many newly described non-helical mollicutes from insect and/or plant hosts that possessed distinct growth requirements (family Entomoplasmataceae, genus Mesoplasma and genus Entomoplasma).

The association of spiroplasmas with insects (10), coupled with the high global biodiversity of insects, should assure the continuing collection of new Spiro- plasma strains. Further evaluation and reclassification of these remarkable prokaryotes will undoubtedly continue to be a taxonomic necessity.

\section{ACKNOWLEDGEMENTS}

The authors gratefully acknowledge the assistance of Mary Fenton in preparation of the electron micrographs.

\section{REFERENCES}

1. Abalain-Colloc, M. L., Williamson, D. L., Carle, P., Abalain, J. H., Bonnet, F., Tully, J. G., Konai, M., Whitcomb, R. F., Bové, J. M. \& Chastel, C. (1993). Division of group XVI spiroplasmas into subgroups. Int J Syst Bacteriol 43, 342-346.

2. Adams, J. R., Whitcomb, R. F., Tully, J. G., Clark, E. A., Rose, D. L., Carle, P., Konai, M., Bové, J. M., Henegar, R. B. \& Williamson, D. L. (1997). Spiroplasma alleghenense sp. nov., a new species from the scorpionfly Planorpa helena (Mecoptera: Panorpidae). Int J Syst Bacteriol 47, 759-762.

3. Aluotto, B. B., Wittler, R. G., Williams, C. O. \& Faber, J. E. (1970). Standardized bacteriologic techniques for characterization of Mycoplasma species. Int $J$ Syst Bacteriol 20 , $35-58$.

4. Bové, J. M., Mouches, C., Carle-Junca, P., Degorce-Dumas, J. R., Tully, J. G. \& Whitcomb, R. F. (1983). Spiroplasmas of group I: the Spiroplasma citri cluster. Yale J Biol Med 56, 573-582.

5. Carle, P., Laigret, F., Tully, J. G. \& Bové, J. M. (1995). Heterogeneity of genome sizes within the genus Spiroplasma. Int J Syst Bacteriol 45, 178-181.

6. Carle, P., Rose, D. L., Tully, J. G. \& Bové, J. M. (1992). The genome size of spiroplasmas and other mollicutes. IOM Lett 2, 263.

7. Carle, P., Saillard, C. \& Bové, J. M. (1983). DNA extraction and purification. Methods Mycoplasmol 1, 295-299.

8. Carle, P., Saillard, C. \& Bové, J. M. (1983). Determination of guanine plus cytosine content of DNA. Methods Mycoplasmol 1, 301-308.

9. Carle, P., Whitcomb, R. F., Hackett, K. J., Tully, J. G., Rose, D. L., Bové, J. M., Henegar, R. B., Konai, M. \& Williamson, D. L. (1997). Spiroplasma diabroticae sp. nov., from the southern corn rootworm beetle Diabrotica undecimpunctata (Coleoptera: Chrysomelidae). Int J Syst Bacteriol 47, 78-80.

10. Clark, T. B. (1982). Spiroplasmas: diversity of arthropod reservoirs and host-parasite relationships. Science 212, 57-59.

11. Clark, T. B., Whitcomb, R. F., Tully, J. G., Mouches, C., Saillard, C., Bové, J. M., Wróblewski, H., Carle, P., Rose, D. L., Henegar, R. B. \& Williamson, D. L. (1985). Spiroplasma melliferum, a new species from the honey bee (Apis mellifera). Int $J$ Syst Bacteriol 35, 296-308.

12. French, F. E., Whitcomb, R. F., Tully, J. G., Carle, P., Bové, J. M., Henegar, R. B., Adams, J. R., Gasparich, G. E. \& Williamson, D. L. (1997). Spiroplasma lineolae sp. nov. from the horse fly Tabanus lineola (Diptera: Tabanidae). Int $J$ Syst Bacteriol 47, 1078-1081.

13. Gasparich, G. E., Saillard, C., Clark, E. A., Konai, M. French, F. E., Tully, J. G., Hackett, K. J. \& Whitcomb, R. F. (1993). Serologic and genomic relatedness of group VIII and group XVII spiroplasmas and subdivision of spiroplasma group VIII into subgroups. Int J Syst Bacteriol 43, 338-341. 
14. Grau, O., Laigret, F., Carle, P., Tully, J. G., Rose, D. L. \& Bové, J. M. (1991). Identification of a plant-derived mollicute as a strain of an avian pathogen, Mycoplasma iowae, and its implications for mollicute taxonomy. Int $J$ Syst Bacteriol 41, 473-478.

15. Gundersen, D. E., Lee, I.-M., Rehner, S. A., Davis, R. E. \& Kingsbury, D. T. (1994). Phylogeny of mycoplasmalike organisms (phytoplasmas): a basis for their classification. $J$ Bacteriol 176, 5244-5254.

16. Guo, Y. H., Chen, T. A., Whitcomb, R. F., Rose, D. L., Tully, J. G., Williamson, D. L., Ye, X. D. \& Chen, Y.X. (1990). Spiroplasma chinense sp. nov. from flowers of Calystegia hederacea in China. Int J Syst Bacteriol 40, 421-425.

17. Hackett, K. J., Clark, E. A., Whitcomb, R. F., Camp, M. \& Tully, J. G. (1996). Amended data on arginine utilization by Spiroplasma species. Int J Syst Bacteriol 46, 912-915.

18. Hackett, K. J., Lynn, D. E., Williamson, D. L., Ginsberg, A. \& Whitcomb, R. F. (1986). Cultivation of the Drosophila sex ratio spiroplasma. Science 232, 1253-1255.

19. Hackett, K. J., Whitcomb, R. F., Clark, T. B., Henegar, R. B., Lynn, D. E., Wagner, A. G., Tully, J. G., Gasparich, G. E., Rose, D. L., Carle, P., Bové, J. M., Konai, M., Clark, E. A., Adams, J. \& Williamson, D. L. (1996). Spiroplasma leptinotarsae sp. nov., a mollicute uniquely adapted to its host, the Colorado potato beetle, Leptinotarsa decemlineata (Coleoptera: Chrysomelidae). Int J Syst Bacteriol 46, 906-911.

20. Hackett, K. J., Whitcomb, R. F., French, F. E., Tully, J. G. Gasparich, G. E., Rose, D. L., Carle, P., Bové, J. M., Henegar, R. B., Clark, T. B., Konai, M., Clark, E. A. \& Williamson, D. L. (1996). Spiroplasma corruscae sp. nov., from a firefly beetle (Coleoptera: Lampyridae) and tabanid flies (Diptera: Tabanidae). Int J Syst Bacteriol 46, 947-950.

21. Hackett, K. J., Whitcomb, R. F., Tully, J. G., Rose, D. L., Carle, P., Bové, J. M., Henegar, R. B., Clark, T. B., Adams, J. \& Williamson, D. L. (1993). Spiroplasma insolitum sp. nov., a new species of group I spiroplasma with an unusual DNA base composition. Int J Syst Bacteriol 43, 272-277.

22. Hélias, C., Vazeille-Falcoz, M., Le Goff, F., Abalain-Colloc, M. L., Rhodain, M., Carle, P., Whitcomb, R. F., Williamson, D. L., Tully, J. G., Bové, J. M. \& Chastel, C. (1998). Spiroplasma turonicum sp. nov. from Haematopota horseflies (Diptera: Tabanidae) in France. Int J Syst Bacteriol 48 (in press)

23. International Committee on Systematic Bacteriology Subcommittee on Taxonomy of Mycoplasmatales (1977). Minutes of interim meeting. 22 September 1976. Int J Syst Bacteriol 27, 392-394.

24. International Committee on Systematic Bacteriology Subcommittee on the Taxonomy of Mollicutes (1995). Revised minimum standards for descriptions of new species of the class Mollicutes (Division Tenericutes). Int J Syst Bacteriol 45, 605-612.

25. Junca, P., Saillard, C., Tully, J. G., Garcia-Jurado, O., DegorceDumas, J. R., Mouches, C., Vignault, J. C., Vogel, R., McCoy. R., Whitcomb, R. F., Williamson, D. L., Latrille, J. \& Bové, J. M. (1980). Caractérisation de spiroplasmes isolés d'insectes et de fleurs de France continentale, de Corse et du Maroc. Proposition pour une classification des spiroplasmes. $C R$ Hebd Seances Acad Sci Ser D 290, 1209-1212.

26. Konai, M., Clark, E. A., Camp, M., Koch, A. L. \& Whitcomb, R. F. (1996). Temperature ranges, growth optima, and growth rates of Spiroplasma (Spiroplasmataceae, class Mollicutes) species. Curr Microbiol 32, 314-319.

27. Konai, M., Whitcomb, R. F., French, F. E., Tully, J. G., Rose, D.
L., Carle, P., Bové, J. M., Hackett, K. J., Henegar, R. B., Clark, T. B. \& Williamson, D. L. (1997). Spiroplasma litorale sp. nov., from tabanid flies (Tabanidae: Diptera) in the Southeastern United States. Int J Syst Bacteriol 47, 359-362.

28. Konai, M., Whitcomb, R. F., Tully, J. G., Rose, D. L., Carle, P., Bové, J. M., Henegar, R. B., Hackett, K. J., Clark, T. B. \& Williamson, D. L. (1995). Spiroplasma velocicrescens $\mathrm{sp}$. nov., from the vespid wasp Monobia quadridens. Int $J$ Syst Bacteriol 45, 203-206.

29. Markham, P. G., Clark, T. B. \& Whitcomb, R. F. (1983). Culture techniques for spiroplasmas from arthropods. Methods Mycoplasmol 2, 217-223.

30. Neimark, H. C. \& Lange, C. S. (1990). Pulsed-field electrophoresis indicates full-length mycoplasma chromosomes range widely in size. Nucleic Acids Res 18, 5443-5448.

31. Neimark, H. C., Tully, J. G., Rose, D. \& Lange, C. (1992). Chromosome size polymorphism among mollicutes. Proceedings of the 9th International Congress of the International Organization for Mycoplasmology. IOM Lett 2 , 261.

32. Pyle, L. E., Corcoran, L. E., Cocks, B. G., Bergemann, A. D., Whitley, J. C. \& Finch, L. R. (1988). Pulsed-field electrophoresis indicates larger-than-expected sizes for mycoplasma genomes. Nucleic Acids Res 16, 6015-6025.

33. Saglio, P., L'Hospital, M., Laflèche, D., Dupont, G., Bové, J. M., Tully, J. G. \& Freundt, E. A. (1973). Spiroplasma citri gen. and $\mathrm{sp}$. n.: a mycoplasma-like organism associated with 'stubborn' disease of citrus. Int J Syst Bacteriol 23, 191-204.

34. Saillard, C., Vignault, J. C., Bové, J. M., Raie, A., Tully, J. G., Williamson, D. L., Fos, A., Garnier, M., Gadeau, A., Carle, P. \& Whitcomb, R. F. (1987). Spiroplasma phoeniceum sp. nov., a plant-pathogenic species from Syria. Int J Syst Bacteriol 37, 106-115.

35. Stevens, C., Tang, A. Y., Jenkins, E., Goins, R. L., Tully, J. G., Rose, D. L., Konai, M., Williamson, D. L., Carle, P., Bové, J. M., Hackett, K. J., French, F. E., Wedincamp, J., Henegar, R. B. \& Whitcomb, R. F. (1997). Spiroplasma lampyridicola sp. nov., from the firefly beetle Photuris pennsylvanicus. Int $J$ Syst Bacteriol 47, 709-712.

36. Toth, K. F., Harrison, N. \& Sears, B. B. (1994). Phylogenetic relationships among members of the class Mollicutes deduced from rps3 gene sequences. Int J Syst Bacteriol 44, 119-124.

37. Tully, J. G. (1983). Dark-field microscopy. Methods Mycoplasmol 1, 35-37.

38. Tully, J. G. (1983). Cloning and filtration techniques for mycoplasmas. Methods Mycoplasmol 1, 173-177.

39. Tully, J. G. (1995). Determination of cholesterol and polyoxyethylene requirements of mollicutes. In Molecular and Diagnostic Procedures in Mycoplasmology, vol. 1, pp. 381-389. Edited by S. Razin \& J. G. Tully. San Diego, CA: Academic Press.

40. Tully, J. G., Bové, J. M., Laigret, F. \& Whitcomb, R. F. (1993) Revised taxonomy of the class Mollicutes: proposed elevation of a monophyletic cluster of arthropod-associated mollicutes to ordinal rank (Entomoplasmatales ord. nov.), with provision for familial rank to separate species with nonhelical morphology (Entomoplasmataceae fam. nov.) from helical species (Spiroplasmataceae), and emended descriptions of the order Mycoplasmatales, family $\mathrm{Myco}$ plasmataceae. Int J Syst Bacteriol 43, 378-385.

41. Tully, J. G. \& Razin, S. (editors) (1996). Appendix. In 
Molecular and Diagnostic Procedures in Mycoplasmology, vol. 2, pp. 460-462. San Diego, CA: Academic Press.

42. Tully, J. G., Rose, D. L., Clark, E., Carle, P., Bové, J. M., Henegar, R. B., Whitcomb, R. F., Colflesh, D. E. \& Williamson, D. L. (1987). Revised group classification of the genus Spiroplasma (class Mollicutes), with proposed new groups XII to XXIII. Int J Syst Bacteriol 37, 357-364.

43. Tully, J. G., Rose, D. L., Yunker, C. E., Carle, P., Bové, J. M., Williamson, D. L. \& Whitcomb, R. F. (1995). Spiroplasma ixodetis sp. nov., a new species from Ixodes pacificus ticks collected in Oregon. Int J Syst Bacteriol 45, 23-28.

44. Wayne, L. G., Brenner, D. J., Colwell, R. R., Grimont, P. A. D., Kandler, P., Krichevsky, M. I., Moore, L. H., Moore, W. E. C., Murray, R. G. E., Stackebrandt, E., Starr, M. P. \& Truper, H. G. (1987). Report of the ad hoc committee on reconciliation of approaches to bacterial systematics. Int J Syst Bacteriol 37, 463-464.

45. Weisburg, W. G., Barns, S. M., Pelletier, D. A. \& Lane, D. J. (1991). 16S ribosomal DNA amplification for phylogenetic study. J Bacteriol 173, 697-703.

46. Weisburg, W. G., Tully, J. G., Rose, D. L., Petzel, J. P., Oyaizu, H., Yang, D., Mandelco, L., Sechrest, J., Lawrence, T. G., Van Etten, J., Maniloff, J. \& Woese, C. R. (1989). A phylogenetic analysis of the mycoplasmas: basis for their classification. $J$ Bacteriol 171, 6455-6467.

47. Whitcomb, R. F. (1983). Culture media for spiroplasmas. Methods Mycoplasmol 1, 147-158.

48. Whitcomb, R. F., Bové, J. M., Chen, T. A., Tully, J. G. \& Williamson, D. L. (1987). Proposed criteria for an interim serogroup classification for members of the genus Spiroplasma (class Mollicutes). Int J Syst Bacteriol 37, 82-84.

49. Whitcomb, R. F., Chastel, C., Abalain-Colloc, M., Stevens, C., Tully, J. G., Rose, D. L., Carle, P., Bové, J. M., Henegar, R. B., Hackett, K. J., Clark, T. B. \& Williamson, D. L. (1993). Spiroplasma cantharicola sp. nov., from cantharid beetles (Coleoptera: Cantharidae). Int J Syst Bacteriol 43, 421-424.

50. Whitcomb, R. F., Chen, T. A., Williamson, D. L., Liao, C., Tully, J. G., Bové, J. M., Mouches, C., Rose, D. L., Coan, M. E. \& Clark, T. B. (1986). Spiroplasma kunkelii sp. nov.: characterization of the etiological agent of corn stunt disease. Int J Syst Bacteriol 36, 170-178.

51. Whitcomb, R. F., Clark, T. B., Tully, J. G., Chen, T. A. \& Bové, J. M. (1983). Serological classification of spiroplasmas. Current status. Yale J Biol Med 56, 453-459.

52. Whitcomb, R. F., French, F. E., Tully, J. G., Carle, P., Henegar, R. B., Hackett, K. J., Adams, J. R. \& Williamson, D. L. (1997). Spiroplasma species, groups, and subgroups from North American Tabanidae. Curr Microbiol 35, 287-293.

53. Whitcomb, R. F., French, F. E., Tully, J. G., Gasparich, G. E., Rose, D. L., Carle, P., Bové, J. M., Henegar, R. B., Konai, M., Hackett, K. J., Adams, J. R., Clark, T. B. \& Williamson, D. L. (1997). Spiroplasma chrysopicola sp. nov., Spiroplasma gladiatoris sp. nov., Spiroplasma helicoides sp. nov., and Spiroplasma tabanidicola $\mathrm{sp}$. nov., from tabanid (Diptera: Tabanidae) flies. Int $J$ Syst Bacteriol 47, 713-719.

54. Whitcomb, R. F., French, F. E., Tully, J. G., Rose, D. L., Carle, P. M., Bové, J. M., Clark, E. A., Henegar, R. B., Konai, M., Hackett, K. J., Adams, J. R. \& Williamson, D. L. (1997). Spiroplasma montanense sp. nov., from Hybomitra horse flies at northern latitudes in North America. Int $J$ Syst Bacteriol 47, 720-723.
55. Whitcomb, R. F., French, F. E., Tully, J. G., Williamson, D. L., Carle, P., Bové, J. M., Henegar, R. B. \& Hackett, K. J. (1992). Identification of Spiroplasma species and groups from tabanid flies. IOM Lett 4, 296-297.

56. Whitcomb, R. F., Gasparich, G. E., French, F. E., Tully, J. G., Rose, D. L., Carle, P., Bové, J. M., Henegar, R. B., Konai, M., Hackett, K. J., Adams, J., Clark, T. B. \& Williamson, D. L. (1996). Spiroplasma syrphidicola sp. nov., from a syrphid fly (Diptera: Syrphidae). Int J Syst Bacteriol 46, 797-801.

57. Whitcomb, R. F. \& Hackett, K. J. (1996). Identification of mollicutes from insects. In Molecular and Diagnostic Procedures in Mycoplasmology, vol. 2, pp. 313-322. Edited by J. G. Tully \& S. Razin. San Diego, CA: Academic Press.

58. Whitcomb, R. F., Hackett, K. J. \& Clark, E. A. (1986). Cloning by limiting dilution in liquid media: an improved alternative for cloning mollicute species. Proceedings of the 6th International Congress on Mycoplasmology, Birmingham, Alabama, August 26-31, p. 167.

59. Whitcomb, R. F., Tully, J. G., Clark, T. B., Williamson, D. L. \& Bové, J. M. (1982). Revised serological classification of spiroplasmas, new provisional groups and recommendations for serotyping of isolates. Curr Microbiol 7, 291-296.

60. Whitcomb, R. F., Tully, J. G., McCawley, P. \& Rose, D. L. (1982). Application of the growth inhibition test to Spiroplasma taxonomy. Int J Syst Bacteriol 32, 387-394.

61. Whitcomb, R. F., Tully, J. G., Rose, D. L., Carle, P., Bové, J. M., Henegar, R. B., Hackett, K. J., Clark, T. B., Konai, M., Adams, J. \& Williamson, D. L. (1993). Spiroplasma monobiae sp. nov., from the vespid wasp Monobia quadridens (Hymenoptera: Vespidae). Int $J$ Syst Bacteriol 43, 256-260.

62. Whitcomb, R. F., Tully, J. G., Williamson, D. L., Bové, J. M., French, F. E., Konai, M., Gasparich, G., Abalain-Colloc, M., Saillard, C., Chastel, C., Carle, P., Rose, D. L., Henegar, R. B., Clark, E. A. \& Hackett, K. J. (1992). Revised classification of spiroplasmas. IOM Lett 2, 134.

63. Whitcomb, R. F., Vignault, J.-C., Tully, J. G., Rose, D. L., Carle, P., Bové, J. M., Hackett, K. J., Henegar, R. B., Konai, M. \& Williamson, D. L. (1993). Spiroplasma clarkii sp. nov. from the green June beetle (Coleoptera: Scarabaeidae). Int J Syst Bacteriol 43, 261-265.

64. Williamson, D. L. (1983). Specialized electron microscopic techniques for spiroplasmas in plant and insect tissues. Methods Mycoplasmol 1, 71-76.

65. Williamson, D. L., Adams, J. R., Whitcomb, R. F., Tully, J. G., Carle, P., Konai, M., Bové, J. M. \& Henegar, R. B. (1997). Spiroplasma platyhelix sp. nov., a new mollicute with unusual morphology and genome size from the dragonfly Pachydiplax longipennis. Int J Syst Bacteriol 47, 763-766.

66. Williamson, D. L. \& Poulson, D. F. (1979). Sex ratio organisms (spiroplasmas) of Drosophila. In The Mycoplasmas, vol. 3, pp. 175-208. Edited by R. F. Whitcomb \& J. G. Tully. New York: Academic Press.

67. Williamson, D. L., Tully, J. G., Rosen, L., Rose, D. L., Whitcomb, R. F., Abalain-Colloc, M.-L., Carle, P., Bové, J. M. \& Smyth, J. (1996). Spiroplasma diminutum sp. nov., from Culex annulus mosquitoes collected in Taiwan. Int $J$ Syst Bacteriol 46, 229-233.

68. Williamson, D. L., Tully, J. G. \& Whitcomb, R. F. (1979). Serological relationships of spiroplasmas as shown by combined deformation and metabolism inhibition tests. Int $J$ Syst Bacteriol 29, 345-351.

69. Williamson, D. L. \& Whitcomb, R. F. (1983). Special sero- 
logical tests for spiroplasma identification. Methods Mycoplasmol 2, 249-259.

70. Williamson, D. L., Whitcomb, R. F. \& Tully, J. G. (1978). The spiroplasma deformation test, a new serological method. Curr Microbiol 1, 203-207.
71. Williamson, D. L., Whitcomb, R. F., Tully, J. G., Gasparich, G., Rose, D. L., Carle, P., Bové, J. M., Hackett, K. J., Henegar, R. B., Konai, M., Chastel, C. \& French, F. E. (1996). Revised group classification of the genus Spiroplasma. IOM Lett 4 , 217. 